An influential group has made a public appeal for subscriptions in order that the scheme may be in full operation by 1940 and it is believed that some of our members will wish to be associated with the work. Cheques, which should be made payable to the Rhodes-Livingstone Trust, may be sent to any branch either of Barclays Bank, Ltd., or of Barclays Bank (Dominions, Colonial, and Overseas) or of the Standard Bank of South Africa, who have kindly agreed to receive them.

\title{
Oxford University Summer School on Colonial Administration.
}

THE success of the first Oxford University Summer School on Colonial Administration (under the Chairmanship of Professor R. Coupland and Miss Margery Perham) exceeded all expectations. It numbered I 70 members, housed at St. Hugh's College, and included administrative officers serving in nearly every British Colony or Protectorate. Africa, and in particular Nigeria, sent by far the largest contingents. The School, which lasted for a fortnight, was formally opened by the Rt. Hon. W. Ormsby Gore, Secretary of State for the Colonies, who emphasized the value of co-operation between those engaged in academic research and those doing the dayto-day work of administration. Lord Lugard gave the inaugural address, in the course of which he said that it would be impossible to overestimate the value of the study of native life. He spoke of premature detribalization as one of the most pressing problems, suggesting that the remedy might be found in making the village community an effective antidote to emigration.

The lecture courses were planned on broad, imaginative lines and covered a wide field. The first week was given up to large-scale surveys of international problems, political and economic (Sir Arthur Salter on world economic policies, Sir Alfred Zimmern on the international outlook, Professor Coupland on the humanitarian tradition, \&c.). Other lecturers gave historical and comparative accounts of the whole development of administrative machinery in countries with widely differing cultures (e.g. Sir Frederick Whyte on the Far East, Professor Laski on the Soviet experiment, Miss Headlam-Morley on the Totalitarian States, Professor Labouret, Professor A. Moeller and Professor de Wilde on the colonial policies of France, Belgium, and Holland respectively). Mr. John Maud discussed local government in England and Sir John Shuckburgh the organization of the British Colonial Office. These wider surveys led the way to more detailed discussions of special administrative problems in the Colonies during the second week. The School then listened to Lord Hailey describing the progress of the African Research Survey and sketching the comparative development of legal and judicial machinery in India and Africa. Sir Donald Cameron spoke on the policy of Indirect Rule, Miss Margery Perham on colonial administration in general, Dr. Lucy Mair on land tenure, Mr. C. F. Strickland on 
co-operative movements, the Rev. J. W. C. Dougall on Christian missions and native society.

Of interest to readers of this Journal were three lectures given by anthropologists (Dr. E. Evans-Pritchard, Dr. Audrey Richards and Dr. S. Nadel) on the services which anthropology could render Colonial Governments. There seemed general agreement as to the value of specialists' work on this subject as distinct from that of officers temporarily seconded from the political service, but there was some discussion as to whether the anthropologist's best contribution took the form of detailed scientific monographs on different tribes written with no practical end in view, or work done by Government anthropologists making regional surveys of different ethnic groups for particular administrative purposes, or ad hoc studies of special problems (land tenure, chiefly succession, \&c.), or as advisers to different Government departments, political, educational and agricultural.

Evening discussions organized by members of the School themselves were much appreciated, and questions such as European settlement, urban native development, migratory labour, the educated native, were debated.

\section{Applied Anthropology in England.}

THE Royal Anthropological Institute of Great Britain has constituted a Standing Committee on Applied Anthropology the object of which is to encourage the study of problems of culture contact and native administration. The Committee will hold meetings for the discussion of practical problems with administrators, missionaries, and others with colonial experience, and will also endeavour to further the preparation of plans of research co-ordinated on a systematic basis. On this more theoretical side it is hoped to stimulate discussion leading to the elucidation of concepts the meaning of which is at present somewhat ambiguous, such as 'cultural stability', 'detribalization', and the like. The Committee has in preparation a memorandum dealing with problems arising out of modern developments in the payment of bride-price among the tribes of Eastern, Central, and Southern Africa, in which the collaboration of experts in a number of territories has been sought. While it would be rare at the present time to find any one in touch with native life who does not appreciate the value of the bride-price custom in its traditional form, the problems which arise from its commercialization in modern conditions are not so fully realized, and it is hoped to contribute something to the understanding of this aspect of the question.

\section{Phénomìnes religieux et cycles culturels en Afrique.}

Sous ce titre le R.P. Dr. Van Bulck a fait au Sixième Congrès International de l'Histoire des Religions à Bruxelles (1935), une communication dont le texte complet vient d'être publié dans la revue Congo (1936, II. I. I-55, et 2. I6I- 